\title{
Formulation of Modified Dense Graded Bituminous Macadam with Low Density and High Density Polythene with Zykotherm Admixture
}

\author{
Vaibhav Srivastava \\ P.G. Scholar \\ Department of Civil Engineering \\ Oriental Institute of Science and \\ Technology \\ Bhopal, M.P, India \\ vaibhavsrivastava194@gmail.com
}

\author{
Akhil Nema \\ Asst. Prof. \\ Department of Civil \\ Engineering \\ Oriental Institute of \\ Science and \\ Technology \\ Bhopal, M.P, India
}

\author{
Pravin Kumar \\ Kushwaha \\ Asst. Prof. \\ Department of Civil \\ Engineering \\ Oriental Institute of \\ Science and \\ Technology \\ Bhopal, M.P, India
}

\author{
Sandeep Shrivastava \\ H.O.D \\ Department of Civil \\ Engineering \\ Oriental Institute of \\ Science and \\ Technology \\ Bhopal, M.P, India
}

\begin{abstract}
This study presents the use of waste polythene derived as carry bags from kitchen waste and pond liner polyethelene as LDPE and bottle caps as HDPE as an additive in flexible pavements. In this study we will also add a fix percentage of zykotherm. Purposes of using above materials are to utilize environmentally unacceptable waste material and to develop a better material mix to resist increased traffic load and temperature effect resulting cracks in the pavement surface.
\end{abstract}

In the proposed study the plastic waste will be cleaned and cut into a size such that it passes through 2-3mm sieve using shredding machine. In this study Dense Bituminous Macadam (DBM) mix will be proposed to prepare by using plain bitumen as a control specimen and bitumen mixed with LDPE $2 \%$ and $4 \%$ \& HDPE $2 \%, 3 \%, 4 \%, 5 \%$ ) as by weight, with fixed percentage of Zykotherm as $1.5 \%$ by weight.Bitumen content is $4.5 \%$ by weight for all specimen. The Marshall Stability test, Penetration Test, and softening point test, were conducted on control and modified DBM mixes.

Keywords: Zykotherm, LDPE, HDPE, Dense Bituminous Macadam, Marshall Stability.

\section{INTRODUCTION}

Polymer modified bitumen is emerging as one of the important construction materials for flexible pavements because of the several reasons. The polymer modified bitumen show better properties for road construction \& plastics waste, otherwise considered to be a pollution menace, can find its use in this process and this can help solving the problem of pollution because most of the plastic waste is polymers. Flexible pavement can be defined as the one consisting of a mixture of asphaltic or bituminous material and aggregates placed on a bed of compacted granular material of appropriate quality in layers over the subgrade. Plastic garbage is commonly seen around the country and has started causing several problems. Plastic waste clogs drains, causing floods. It chokes animals who eat plastic bags, etc.

Non-Biodegradable wastes are those that cannot break down or degrade for many years, they cannot be changed into manure and burning of these fuels causes more pollution in the environment thus to overcome this problem it can be utilized in construction industry.

\section{LDPE}

Low Density Polyethylene (LDPE) includes house hold polythene and pond liner polyethelene gathered from neighborhood dump destinations washed with cleanser and water and destryed into size of $2 \mathrm{~mm}$ to 3 $\mathrm{mm}$.

- It has a density from 0.910 to $0.940 \mathrm{~g} / \mathrm{cm}$ cube.

- $\quad$ Specific Gravity is 0.92 .

- Melting temperature is greater than $110^{\circ} \mathrm{C}$. 


\section{HDPE}

The thickness of HDPE is subtly higher than the low density polyethelene and inclides bottles ,bottles caps etc.

The density of HDPE can keep running from 0.93 to $0.97 \mathrm{~g} / \mathrm{cm}$ cube

Melting temperature is greater than $130^{\circ} \mathrm{C}$.

\section{Zyco Therm}

The additive used was supplied and produced by Zydex Industries, based in Gujarat, India. This additive is soluble in water and generates polymeric material and alcohol when exposed to moisture but is stable under normal temperatures and pressures.

It consists of $65 \%$ to $75 \%$ hydroxyalkyl-alkoxyalkylsilyl compounds, $25 \%$ to $27 \%$ benzyl-alcohol and $3 \%$ to $5 \%$ ethylene glycol.

\section{LITERATURE REVIEW}

Mohd. Rosli et. al. (2017) [Performance characterizations of asphalt binders and mixtures incorporating silane additive ZycoTherm] In this study, $0.1 \mathrm{wt} \%$ ZycoTherm was blended with asphalt binder to enable production of asphalt mixture at lower than normal temperatures, as well as improve mix workability and compactability. The properties of control asphalt binders (60/70 and 80/10 penetration grade) and asphalt binders incorporating $0.1 \%$ ZycoTherm were reported based on the penetration, softening point, rotational viscosity, complex modulus and phase angle. Subsequently, to compare the performance of asphalt mixture incorporating ZycoTherm with the control asphalt mixture, cylindrical samples were prepared at recommended temperatures and air voids depending on the binder types and test requirements. The samples were tested for indirect tensile strength (ITS), resilient modulus, dynamic creep, Hamburg wheel tracking and moisture induced damage. From compaction data using the Servopak gyratory compactor, specimen prepared using ZycoTherm exhibit higher workability and compactability compared to the conventional mixture. From the mixture performance test results, mixtures prepared with ZycoTherm showed better performance in terms of the resistance to moisture damage, permanent deformation and cracking.

Dr. Malik Shoeb Ahmad (2014) [Low Density Polyethylene Modified Dense Graded Bituminous Macadam ] Reclaimed plastic waste derived from low density polyethylene (LDPE/PW) carry bags from kitchen waste and plastic bottles have been used as additive in flexible pavements. In the present study the plastic waste was cleaned and cut into a size such that it passes through $2-3 \mathrm{~mm}$ sieve using shredding machine. In this study Dense Bituminous Macadam (DBM) mix has been prepared by using plain bitumen as a control specimen and bitumen mixed with low density polyethylene (LDPE/PW) in different proportions such as $2,4,6,8,10$ and $12 \%$ by weight.

The Marshall Stability tests were conducted on control and modified DBM mixes. It has been observed that the plastic waste modified bitumen mix show better binding property, stability, density and more resistant to water. The test performed by author results showed that the stability of DBM mixes was improved significantly on addition of plastic wastes to the mixes. Hence, the present study will result lesser road repairs and use of plastic wastes will help to utilize non biodegradable waste. The addition of LDPE (PW) reduces the air voids which prevents the moisture absorption and oxidation of bitumen by entrapped air. This has resulted in enhancement of Marshall Stability value. It has been observed that the stability values of mixes modified with plastic waste have been increased significantly up to the tune of $14 \%$ at $12 \%$ waste as compared to mix prepared with plain bitumen. This shows the enhancement in strength of the mix due to addition of plastic waste which signifies that the inclusion of plastic waste increases the density of the mix. The bulk density of the mix was also increasing with increase in the plastic waste content. The most significant percentage of waste is observed as $12 \%$ at which the density is maximum $(2.51 \mathrm{~g} / \mathrm{cc})$ which is about $25 \%$ more than the density of the mix prepared with plain bitumen.

Rohith N, J. Ranjitha (2013) [A Study On Marshall Stability Properties Of Warm Mix Asphalt Using Zycotherm A Chemical Additive] Here the author made an attempt to compare the marshall properties of WMA produced with the chemical additives :"Zyco Therm" and HMA for Dense Bituminous Macadam(DBM) Grade 2. The adopted mixing temperatures for $\mathrm{HMA}$ was $155^{\circ} \mathrm{C}, 130^{\circ} \mathrm{C}$ and $115^{\circ} \mathrm{C}$ and the mixing temperatures for WMA was $130^{\circ} \mathrm{C}$ and $115^{\circ} \mathrm{C}$, with an additive dosage rate of $0.1 \%$ by weight of the binder.. The laboratory study concludes that Stability \& Marshall properties were improved for the WMA mix by the addition of the additive. The present study includes the preparation and testing of laboratory specimens for Marshall Test of HMA mix at $155^{\circ} \mathrm{C}$, 
$130^{\circ} \mathrm{C}$ and $115^{\circ} \mathrm{C}$ temperature and WMA mix at $130^{\circ} \mathrm{C}$ and $115^{\circ} \mathrm{C}$ temperature with additive dosage rate of $0.1 \%$ by weight of binder, to the required specifications.

The Marshall Stability value of HMA specimens produced at $155^{\circ} \mathrm{C}$ has good stability values. When compared with HMA specimens, the stability and Marshall Properties of WMA specimens prepared at $130^{\circ} \mathrm{C}$ and $115^{\circ} \mathrm{C}$ were improved by the addition of Zycotherm at an additive dosage rate of $0.1 \%$ by weight of the binder. The optimum binder content for the HMA mix at $155^{\circ} \mathrm{C}$ was found out to be $5.4 \%$ and WMA mix at $130^{\circ} \mathrm{C}$ with $0.1 \%$ of ZycoTherm was found out to be $5.37 \%$. This concludes that the optimum binder content for HMA and WMA mix are different with varying the temperature and additive dosage rate, so the OBC should be found out individually for both HMA and WMA mix for varying temperatures and additive dosage rate.

\section{PROBLEM IDENTIFICATION}

The researchers have tried to find the variation in Bituminous samples which occurs due to admixtures and utilization of waste materials following are the outcomes of literature review:

Specimen prepared using ZycoTherm exhibit higher workability and compactability compared to the conventional mixture From the mixture performance test results, mixtures prepared with Zyco Therm showed comparable better performance than the control sample in terms of the resistance to moisture damage, permanent deformation and cracking. The unique, organo-silane chemistry of ZycoTherm, gives, a strong and permanent chemical bonding ( $\mathrm{Si}-\mathrm{O}-\mathrm{Si}-$ mother nature bond available in sand/quartz) between the bitumen and the aggregate surface. The permanent chemical bonding enables excellent moisture resistance, complete coating of bitumen on aggregates and allows wider temperature zone for mixing and compaction resulting in a pavement with extended life cycle. The addition of LDPE reduces the air voids which prevents the moisture absorption and oxidation of bitumen by entrapped air. This has resulted in enhancement of Marshall Stability value, and more resistant to water.

It has been observed that the plastic waste modified bitumen mix show better binding property, stability.

\section{OBJECTIVES}

1. To study the effects of mixing LDPE, HDPE and Zykotherm in Hot mix asphalt.

2. To determine which sample is more stable and performing well in comparing all cases.

3. To determine the enhancement in properties of hot mix asphalt using LDPE. and HDPE.

4. To determine the optimum percentage of HDPE and LDPE in a mix.

\section{METHODOLOGY}

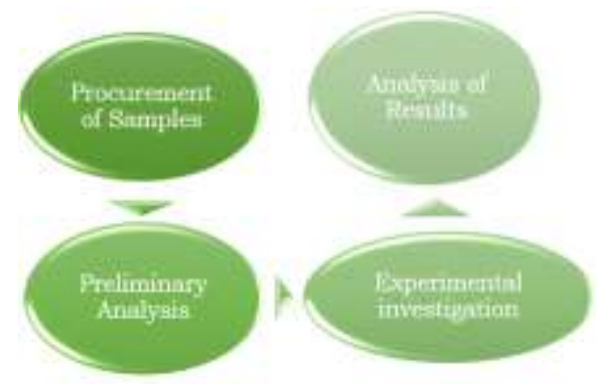

Fig 1: Flow chart of the study

The procedure followed for conducting the tests is as per outline of Marshall Method (ASTM: D-1559).

Marshall Tests for stability and flow are conducted on three specimens for each sample of bituminous mix without zycotherm and plastic, and with combination of Zycotherm and plastic. Bitumen content of $4.5 \%$ is constant for all the specimen.

Marshal Properties have been determined for each mix with varying percentage (2-5) of HDPE \&2-4\% (LDPE).

In the present investigation an attempt is made to study the enhancement in the properties of Hot mix Asphalt (HMA) on adding polythene (LDPE \& HDPE) and combination of Zycotherm and Plastic waste.

\section{EXPERIMENTAL RESULTS}

Table 1: 2\% LDPE results

\begin{tabular}{|l|c|c|}
\hline \multicolumn{3}{|c|}{ Marshall Stability test with 2\% LDPE } \\
\hline Type of Mix & $\begin{array}{l}\text { Marshall } \\
\text { Stability } \\
\text { value (kg) }\end{array}$ & $\begin{array}{l}\text { Flow } \\
\text { Value(mm) }\end{array}$ \\
\hline $\begin{array}{l}\text { HMA mix with 2\% } \\
\text { HDPE }\end{array}$ & 1560 & 3.5 \\
\hline $\begin{array}{l}\text { HMA mix with 3\% } \\
\text { HDPE }\end{array}$ & 1640 & 3.8 \\
\hline
\end{tabular}




\begin{tabular}{|l|c|c|}
\hline $\begin{array}{l}\text { HMA mix with } 4 \% \\
\text { HDPE. }\end{array}$ & 1700 & 4.1 \\
\hline $\begin{array}{l}\text { HMA mix with } 5 \% \\
\text { HDPE }\end{array}$ & 1686 & 4 \\
\hline
\end{tabular}

\begin{tabular}{|r|c|c|}
\hline SAMPLE 2 & $3 \%$ & 57.33 \\
\hline SAMPLE 3 & $4 \%$ & 68.33 \\
\hline SAMPLE 4 & $5 \%$ & 64.67 \\
\hline
\end{tabular}

Table 4: Penetration test for 4\% LDPE

Table 2: 4\% LDPE results

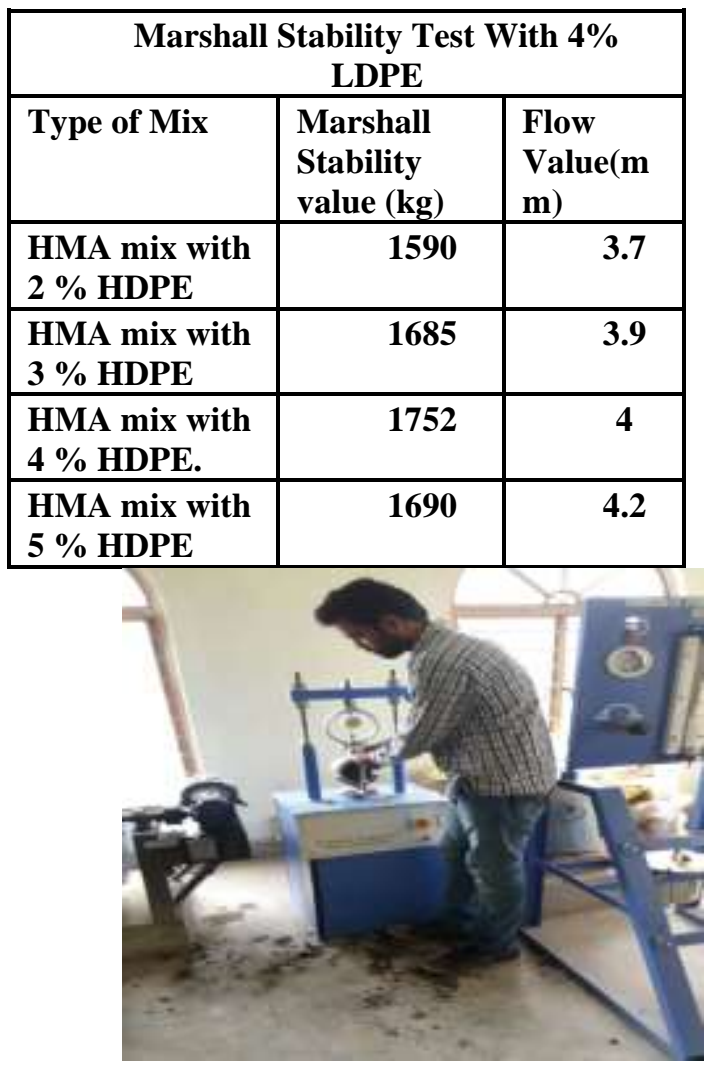

\begin{tabular}{|c|c|c|}
\hline \multicolumn{3}{|c|}{ PENETRATION TEST 4\% LDPE } \\
\hline SAMPLE & HDPE \% & VALUE (mm) \\
\hline SAMPLE 1 & $2 \%$ & 61.33 \\
\hline SAMPLE 2 & $3 \%$ & 62.67 \\
\hline SAMPLE 3 & $4 \%$ & 69.33 \\
\hline SAMPLE 4 & $5 \%$ & 63 \\
\hline
\end{tabular}
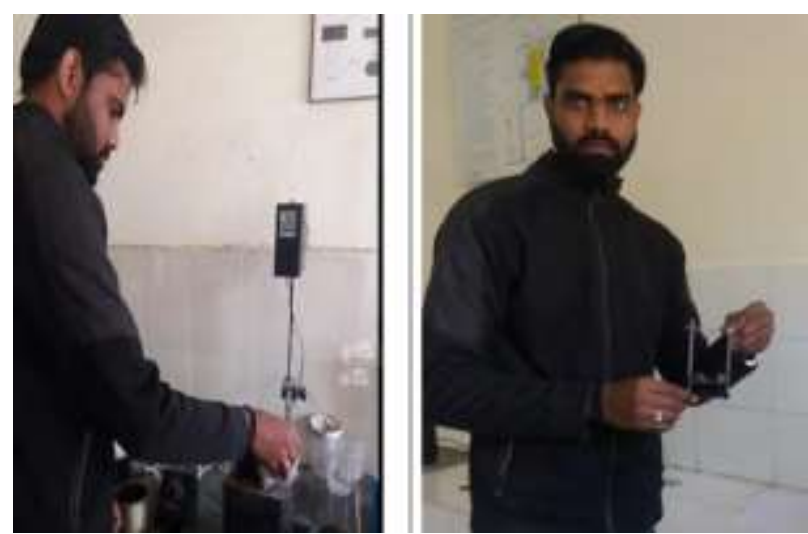

Fig 4: Softening point test

Table 5: Softening point test

Fig 2: Stability test

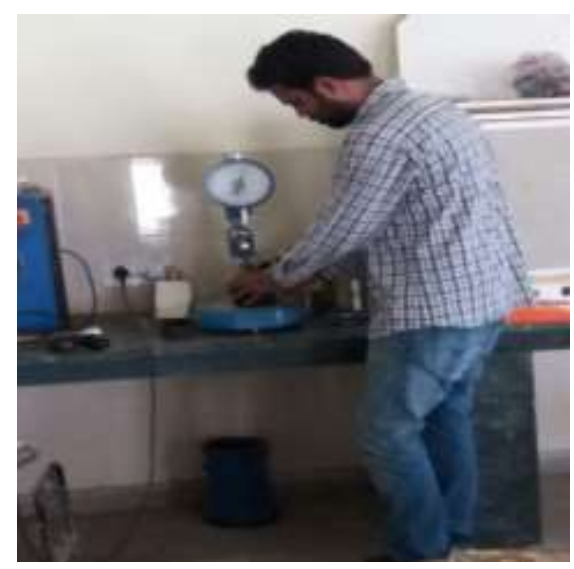

Fig 3: Penetration test

Table 3: Penetration test for 2\% LDPE

\begin{tabular}{|c|c|c|}
\hline \multicolumn{3}{|c|}{ PENETRATION TEST 2\% LDPE } \\
\hline SAMPLE & HDPE \% & VALUE $(\mathbf{m m})$ \\
\hline SAMPLE 1 & $2 \%$ & 55.33 \\
\hline
\end{tabular}

\begin{tabular}{|l|l|c|c|c|}
\hline $\begin{array}{l}\text { LDPE } \\
\%\end{array}$ & $\begin{array}{c}\text { HDPE } \\
\%\end{array}$ & $\begin{array}{c}\text { Marshall } \\
\text { stability }\end{array}$ & Penetration(67.69) & $\begin{array}{c}\text { Softening } \\
\text { oint }\left(47.5^{\circ}\right. \\
\text { C) }\end{array}$ \\
\hline $\begin{array}{l}2 \% \\
\text { LDPE }\end{array}$ & $\begin{array}{l}2 \% \\
\text { HDPE }\end{array}$ & $1560 \mathrm{~kg}$ & $55.33 \mathrm{~mm}$ & $54.1^{\circ} \mathrm{C}$ \\
\hline $\begin{array}{l}2 \% \\
\text { LDPE }\end{array}$ & $\begin{array}{l}3 \% \\
\text { HDPE }\end{array}$ & $1640 \mathrm{~kg}$ & $57.33 \mathrm{~mm}$ & $54.7^{\circ} \mathrm{C}$ \\
\hline $\begin{array}{l}2 \% \\
\text { LDPE }\end{array}$ & $\begin{array}{l}4 \% \\
\text { HDPE }\end{array}$ & $1700 \mathrm{~kg}$ & $68.33 \mathrm{~mm}$ & $55.1^{\circ} \mathrm{C}$ \\
\hline $\begin{array}{l}2 \% \\
\text { LDPE }\end{array}$ & $\begin{array}{l}5 \% \\
\text { HDPE }\end{array}$ & $1686 \mathrm{~kg}$ & $64.67 \mathrm{~mm}$ & $55.8^{\circ} \mathrm{C}$ \\
\hline $\begin{array}{l}4 \% \\
\text { LDPE }\end{array}$ & $\begin{array}{l}2 \% \\
\text { HDPE }\end{array}$ & $1590 \mathrm{~kg}$ & $61.33 \mathrm{~mm}$ & $54.8^{\circ} \mathrm{C}$ \\
\hline $\begin{array}{l}4 \% \\
\text { LDPE }\end{array}$ & $\begin{array}{l}3 \% \\
\text { HDPE }\end{array}$ & $1685 \mathrm{~kg}$ & $62.67 \mathrm{~mm}$ & $55.3^{\circ} \mathrm{C}$ \\
\hline $\begin{array}{l}4 \% \\
\text { LDPE }\end{array}$ & $\begin{array}{l}4 \% \\
\text { HDPE }\end{array}$ & $1752 \mathrm{~kg}$ & $69.33 \mathrm{~mm}$ & $56.3^{\circ} \mathrm{C}$ \\
\hline $\begin{array}{l}4 \% \\
\text { LDPE }\end{array}$ & $\begin{array}{l}5 \% \\
\text { HDPE }\end{array}$ & $1690 \mathrm{~kg}$ & $63 \mathrm{~mm}$ & $56.2^{\circ} \mathrm{C}$ \\
\hline
\end{tabular}


From this study the following results are obtained which is shown in Tables and graphs Marshall Properties, Penetration value and Softening point of various Bituminous Mixes. In all cases percentage of
Zycotherm is fixed as $1.5 \%$ and LDPE polythene as $2 \%$ and $4 \%$ by weight whereas percentage of HDPE polythene percentage varies from 2 to $5 \%$ by weight.

\section{COST ANALYSIS}

\begin{tabular}{|c|c|c|c|c|c|c|c|c|}
\hline Bitumen $100 \%$ & Nos & $\mathbf{L}(\mathbf{m})$ & $\mathbf{B}(\mathbf{m})$ & $\mathbf{D}(\mathbf{m})$ & QUANTITY & UNIT & \begin{tabular}{|l} 
RATE \\
(Rs.)
\end{tabular} & $\begin{array}{l}\text { AMOUNT } \\
\text { (Rs.) }\end{array}$ \\
\hline $\begin{array}{l}\text { Providing and laying semi dense } \\
\text { bituminous concrete with Appropriate } \\
\text { batch type HMP using crushed } \\
\text { aggregates of specified grading, } \\
\text { premixed with bituminous binder @ } \\
4.5 \text { to } 5 \text { per cent of mix and filler, } \\
\text { transporting the hot mix to work site, } \\
\text { laying with a hydrostatic paver finisher } \\
\text { to the required grade, level and } \\
\text { alignment, rolling with smooth } \\
\text { wheeled, vibratory and tandem rollers } \\
\text { to achieve the desired compaction as } \\
\text { per MORTH specification clause No. } \\
508 \text { complete in all respects }\end{array}$ & 1 & 1000 & 5.5 & 0.02 & 110 & Cum & & \\
\hline $\begin{array}{l}\text { Grading II layer Thickness }(25-30 \mathrm{~mm}) \\
\text { Bitumen (VG-30) }\end{array}$ & & & & & 17.38725 & Cum & & \\
\hline $\begin{array}{l}\text { Quantity of extra widening at Curves } \\
\text { (As per Annexure-A1) }\end{array}$ & & & & & $\mathbf{0}$ & & & \\
\hline $\begin{array}{l}\text { Extra Widening of CD portion (As per } \\
\text { Annexure-A2) }\end{array}$ & & & & & 2.671875 & Cum & & \\
\hline $\begin{array}{l}\text { Extra Quantity of Juntion portion (As } \\
\text { per Annexure-A3) }\end{array}$ & & & & & 130.059125 & Cum & 9188 & 1194983.241 \\
\hline As per $4 \%$ Ldpe \& $4 \%$ Hdpe & & & & & 119.654395 & Cum & 9188 & 1099384.581 \\
\hline Saving & & & & & 10.40473 & Cum & 9188 & 95598.65924 \\
\hline
\end{tabular}


DOI: https://doi.org/10.24113/ijoscience.v5i5.203

\section{CONCLUSION}

In this study we stated that with the use of LDPE, HDPE polythene and fixed proportion of zycotherm we can increase the property of the sample as well as the binding property of the sample also increases.

This study is valuable for highway construction as it can help in settling the non- biodegradable waste as well as increases bitumen (flexible) pavement life.

\section{From the above tests conducted the following conclusions were drawn out:-}

- Marshall Test conducted on bituminous mix with combination of $4 \%$ LDPE and $4 \%$ HDPE and $1.5 \%$ Zycotherm have higher value of stability $1752 \mathrm{~kg}$ correspondingly the values of flow is 4 .

- It is observed that by addition of polyethylene HDPE to the mixture, the resistance to moisture susceptibility of mix also increases.

- From the study it is concluded that zycotherm increases the binding property of the mix in a natural way .

- As per the cost cutting in construction this method is very valuable and as it is very helpful in cost cutting of bitumen in a mix.

- By the use of zycotherm,

\section{REFERENCES}

[1] Reinke and Glidden year (2002) Effects of High density polythene on the permanent deformation of asphalt concrete. Indian Journal of Engineering and Material Science. 12: 456-460.

[2] Mohammad T et. al. year (2007)" Viscous properties and microstructure of recycled over modified bitumen. Fuel 83(1): 31-38.

[3] Awwad and Shbeebyear (2007) "Influence of the processing conditions on the rheological behavior of polymer-modified bitumen. Fuel. 82(11): 1339-1348

[4] Fernandes et al. year (2008)" Relation between polymer architecture and nonlinear visco elastic behavior of modified asphalts. Current Opinion in Colloid and Interface Science. 11: 230-245.

[5] Sabina et al. year (2009) "Warm Mix Asphalt Paving Technologies: a Road Builder's Perspective" Paper presentation of annual conference Transportation Association of Canada".

[6] Yousefiyear (2009)" Bitumen modification with reactive and non-reactive (virgin and recycled) polymers: A comparative analysis. Journal of Industrial and Engineering Chemistry. 15(4): 458-464.

[7] Bindu and Beenayear (2010) "Performance of Low-Carbon Environmental Warm Mix Asphalt”, American Society of Civil Engineers".
[8] Albasheeret. al. year (2011) "Evaluation of Aspha-Min zeolite for use in warm mix asphalt." National Center for Asphalt Technology Report 05-04. Auburn University, Auburn, Alabama.

[9] Gawande year (2012) "Specifications for Roads and Bridge Works"- 2004, Fifth revision, Indian Roads Congress, New Delhi.

[10] Khan and Gundaliyayear (2012) "Laboratory Evaluation of Warm Asphalt Technology for use in Virginia." Virginia Transportation Research Council Report. In cooperation with the U.S Department of Transportation, VTRC 09-R11.

[11] Rohith N, J. Ranjitha (2013) “A Study On Marshall Stability Properties Of Warm Mix Asphalt Using Zycotherm A Chemical Additive" International Journal of Engineering Research \& Technology (IJERT) ISSN: 22780181, Vol. 2 Issue 7, July - 2013

[12] Mutiu Akinpelu1, Bamidele I. O. Dahunsi, Oladipupo Olafusi, Olufemi S Awogboro (2013) [EFFECT OF POLYTHENE MODIFIED BITUMEN ON PROPERTIES OF HOT MIX ASPHALT], ARPN Journal of Engineering and Applied Sciences, ISSN 1819-6608, Vol. 8, No. 4, April 2013

[13] Liliana M.B. Costa year (2013) "Evaluation Of The Cecabase Warm-Mix Additive", University Of Nevada Reno, in association with CECA Arkema Group, Nevada 89557.

[14] Mohammed Sadequeet. (2014) Mix Design Methods for Asphalt Concrete and Other Hot-Mix types, Manual Series No.2, Sixth Edition, Asphalt Institute, Lexington, Kentucky.

[15] Malik Shoeb Ahmad year (2014) Highway Material testing (Laboratory Manual), Nemchand and Bros, Roorkee 1997.

[16] Dr. Malik Shoeb Ahmad (2014) [Low Density Polyethylene Modified Dense Graded Bituminous Macadam ], International Journal of Engineering Trends and Technology (IJETT) - Volume 16 Number 8 - Oct 2014

[17] Tariq Ali, Nouman Iqbal.et.at (2014) [Sustainability Assessment of Bitumen with Polyethylene as Polymer], IOSR Journal of Mechanical and Civil Engineering (IOSRJMCE), e-ISSN: 2278-1684, p-ISSN: 2320-334X, Volume 10, Issue 5 (Jan. 2014), PP 01-06

[18] Mohd. Rosli Mohd. Hasan, TekSek Yee.et.at (2017) "Performance characterizations of asphalt binders and mixtures incorporating silane additive ZycoTherm" School of Civil Engineering, Universiti Sains Malaysia (Engineering Campus), 14300 Nibong Tebal, Pulau Pinang

[19] Divya V, Gyanen Takhelmayum (2017) "Evaluation of Laboratory Performance of Sasobit and Zycothermas An Additives for Warm Mix Asphalt on Performance Characteristic" International Journal of Advances in Scientific Research and Engineering (IJASRE) Vol.3, Special Issue 1 Aug - 2017

[20] Johnson KwabenaAppiaha, Victor Nana Berko-Boatenga, Trinity Ama Tagbor (2017) Use of waste plastic materials for road construction in Ghana] Council for Scientific and Industrial Research-Building and Road Research Institute, CSIR-BRRI, Kumasi, Ghana 